\title{
Highlights of an Expert Advisory Board on Acute Exacerbations of Chronic Obstructive Pulmonary Disease (AE-COPD) in Latin America
}

This article was published in the following Dove Press journal: International Journal of Chronic Obstructive Pulmonary Disease

\author{
Laura Naranjo' \\ Carlos A Torres-Duque (iD) ${ }^{2}$ \\ Daniel Colodenco ${ }^{3}$ \\ Gustavo Lopardo (iD) 4 \\ Pablo Rodriguez (D) ${ }^{5}$ \\ Aldo Agra de Albuquerque- \\ Neto (iD ${ }^{6}$ \\ Rafael J Hernandez- \\ Zenteno $^{7}{ }^{7}$ \\ Luis Septien ${ }^{8}$ \\ Reynaldo Chandler ${ }^{9}$ \\ Eduardo Ortega-Barria' \\ Patricia Juliao iD \\ Adriana Guzman-Holst (iD) \\ 'GSK, Panama City, Panama; ${ }^{2}$ Fundación \\ Neumológica Colombiana, Bogota, \\ Colombia; ${ }^{3}$ Director of Pneumology \\ Specialization Course, University of Buenos \\ Aires, Buenos Aires, Argentina; ${ }^{4} \mathrm{FUNCEI}-$ \\ Bernardo Houssay Hospital, Buenos Aires, \\ Argentina; ${ }^{5}$ Pulmonary and Critical Care \\ Medicine, CEMIC, Buenos Aires, Argentina; \\ ${ }^{6}$ Pulmonary Rehabilitation Unit, Federal \\ University of São Paulo (UNIFESP), São \\ Paulo, Brazil; ${ }^{7}$ MSc Head of COPD Clinic at \\ National Institute of Respiratory Diseases, \\ Mexico City, Mexico; ${ }^{8}$ Pulmonary and \\ Critical Care Division, National Institute of \\ Nutrition Salvador Zubiran, Mexico City, \\ Mexico; ${ }^{9}$ Education and Investigation \\ Coordination Unit, San Miguel Arcangel \\ Hospital, Ministry of Health, Panama City, \\ Panama
}

Correspondence: Adriana Guzman-Holst; Patricia Juliao

GSK, Ciudad Del Saber, Building 230,

Panama City, Panama

Tel +507 2632204

Email adriana.x.guzman@gsk.com;

patricia.d.juliao@gsk.com
Background: Chronic obstructive pulmonary disease (COPD) is a preventable and usually progressive lung disease that affects millions of people worldwide and is the sixth leading cause of death in the Americas. Viral and bacterial respiratory tract infections and air pollution may cause acute exacerbations of COPD (AE-COPD) ranging from mild, moderate to severe. The greatest proportion of the overall COPD burden on the health system is due to disease exacerbations. There is limited evidence regarding the etiology and burden of AE-COPD in Latin America (LATAM).

Methods: To respond to this gap in evidence, an Advisory Board with regional pneumologists and infectious disease experts was convened in September 2018 in Panama City, Panama, to: 1) review the burden of AE-COPD in LATAM; 2) evaluate the etiology of AECOPD in LATAM; and 3) assess and compare the local/regional guidelines to confirm the etiology, characterize, and manage AE-COPD.

Results: The results of the meeting showed that there is a high prevalence of AE-COPD in LATAM countries, limited evidence on etiology data, and discrepancies in the case definitions and symptomology (ie, severity) classifications used in LATAM.

Conclusion: The Advisory Board discussions further resulted in recommendations for future research on the impact on the epidemiology and burden of disease, on establishing standardized AE-COPD case definition guidelines, and on studying the etiology of both moderate and severe AE-COPD cases.

Keywords: COPD, exacerbations, diagnosis, epidemiology, etiology, consensus

\section{Introduction}

Chronic obstructive pulmonary disease (COPD) is a progressive lung disease characterized by persistent airflow limitation. ${ }^{1}$ Chronic inflammation of the lung leads to structural changes that limit the ability of the airways to remain sufficiently open, especially during expiration, ${ }^{2}$ causing chronic airflow limitation, breathlessness, abnormal sputum, and chronic cough. ${ }^{1}$ COPD should be suspected in any patient with these symptoms or a history of exposure to risk factors, mainly smoking, indoor exposure to biomass fuels for cooking or heating, or occupational or environmental air pollution. The clinical diagnosis is confirmed by demonstration of airflow limitation in spirometry after the administration of a bronchodilator. A fixed ratio of the forced expiratory volume in one second $\left(\mathrm{FEV}_{1}\right)$ to the forced vital capacity (FVC) below 0.70 is evidence of the presence of COPD. ${ }^{2,3}$ Sub-classification into the stages of the Global Initiative for Chronic Obstructive Lung Disease (GOLD) Strategy ${ }^{2}$ or into one of the four stages 
from mild to very severe of the Latin American Thoracic Society COPD Guideline ${ }^{4}$ is then performed, depending on the $\mathrm{FEV}_{1}$ value, and graded from A to D based on symptoms and the exacerbation rate. ${ }^{2,4,5}$

COPD affects 210 million people worldwide ${ }^{5}$ and is among the most frequent causes of death and morbidity. ${ }^{2}$ It was the sixth leading cause of death in 2010 in the Americas, accounting for about $23 \%$ of premature deaths in the 30-69 year age group. ${ }^{1}$ The greatest proportion of the overall COPD burden on the healthcare system is due to disease exacerbations. ${ }^{2}$ Viral and bacterial pathogens (ie, nontypeable Haemophilus influenzae (NTHi) and Moraxella catarrhalis) and air pollution may trigger acute exacerbation of COPD (AE-COPD), leading to worsening of lung function and symptoms. ${ }^{1,2}$ Viral infectioninduced AE-COPDs are often more severe and last longer. ${ }^{2}$ The GOLD guidelines define exacerbations as acute worsening of symptoms requiring additional treatment. ${ }^{2}$ AE-COPDs are classified as mild when they can be treated with short acting bronchodilators (SABs), moderate when the outpatient requires the addition of antibiotics and/or oral corticosteroids, and severe when the patient needs to be hospitalized, due to the possibility of developing respiratory failure. ${ }^{2}$ Furthermore, patients with infectious AE-COPD usually complain of upper respiratory infection symptoms, worsening of dyspnea, wheezing, and increased volume and purulence of sputum. ${ }^{6}$ Half of COPD exacerbations are never reported to treating physicians. ${ }^{2,7}$ Patients with moderate to severe COPD experience 2.5 to 3 episodes of $\mathrm{AE}-\mathrm{COPD}^{7}$ per year with a negative impact on disease/symptom progression, ${ }^{2}$ requiring hospital readmission, ${ }^{7}$ and ultimately causing severe impairment ${ }^{8}$ of quality of life and even mortality. ${ }^{9}$ Preventing exacerbations is the end goal in the adequate management of COPD. ${ }^{10}$ In five major Latin America (LATAM) cities, São Paulo (Brazil), Santiago (Chile), Mexico City (Mexico), Montevideo (Uruguay), and Caracas (Venezuela), 18.2\% of COPD patients reported having experienced at least one exacerbation, ranging from 0.13 to 6.78 exacerbations per year, with a frequency mainly depending on COPD severity. ${ }^{11}$ A meta-analysis of Brazilian and Mexican national databases reported that 35 of every 1000 hospitalizations were due to COPD, with an increasing number of hospitalizations with age. ${ }^{12}$ A pharmacoeconomic study conducted in seven LATAM countries, Argentina, Brazil, Colombia, Ecuador, Mexico, Peru, and Venezuela, reported that exacerbations impose a significant cost on the healthcare system, with therapeutic failure being responsible for most of this cost $(52 \%){ }^{13}$

Unfortunately, COPD is underdiagnosed or not diagnosed until the disease has progressed to the more advanced stages. ${ }^{14-16}$ Moreover, many studies from different countries have shown that general practitioners (GPs) very often do not follow the scientific guidelines regarding diagnostic procedures, by not making full use of spirometry or underestimating the patient's exacerbation history. ${ }^{17-21}$ The three most important factors in the GOLD guidelines that should guide treatment decisions are symptoms, spirometry, and exacerbation history. It is important to note that the updated 2019 GOLD guidelines state that spirometry is not part of the treatment classification system anymore; nevertheless, spirometry results are still crucial in the consideration of other therapeutic approaches. In the LATAM region, the exacerbation history of an individual is not usually considered as much as the other approaches; for example, about $64 \%$ of GPs in Mexico reported using spirometry to diagnose. Symptom evaluation was more likely to influence GPs' treatment recommendations, with $74 \%$ in Mexico, $76 \%$ in Brazil, and $84 \%$ in Argentina. ${ }^{18}$

Given the high burden of COPD and the limited data published on the AE-COPD burden in LATAM, an Advisory Board meeting with pulmonologist and infectious disease experts was convened in the region. The meeting objectives were:

1. Review the burden of AE-COPD in LATAM

2. Evaluate etiology patterns of AE-COPD in LATAM

3. Assess and compare the local/regional guidelines to confirm the etiology, characterize, and manage AECOPD in LATAM

\section{Methods}

The AE-COPD LATAM Advisory Board (AdBoard) meeting took place in Panama City on September 27, 2018. The members of the AdBoard were pulmonologists and infectious disease experts in the LATAM region, selected based on their expertise in the field and participation in development of local/regional AE-COPD guidelines (Table 1). The meeting was facilitated by employees of GSK from the LATAM region who are experts on infectious diseases, respiratory diseases, health outcomes, epidemiology, and clinical research.

A stepwise approach consisting of the following three phases was adopted for the AdBoard. 
Table I Members of the Advisory Board: (A) Advisory Board Scientific Experts from the LATAM Region, (B) GSK Specialists

\begin{tabular}{|c|c|c|}
\hline \multicolumn{3}{|c|}{ (A) Lung Specialists from the LATAM Region } \\
\hline Country & Name & Specialty \\
\hline \multirow[t]{3}{*}{ Argentina } & Daniel Colodenco & $\begin{array}{l}\text { - Former chief of Immunology, Maria Ferrer Hospital Buenos Aires } \\
\text { - Director of Pulmonology Postgraduate Course, University of Buenos } \\
\text { Aires } \\
\text { - Former president of Argentine Respiratory Association of } \\
\text { Respiratory Medicine } \\
\text { - Co-Director of EPOC.AR Study }\end{array}$ \\
\hline & Gustavo Lopardo & $\begin{array}{l}\text { - Hospital Bernardo Houssay, Buenos Aires } \\
\text { - Fundacion Centro de Estudios Infectologicos } \\
\text { - Professor of infectious diseases, Universidad de Buenos Aires }\end{array}$ \\
\hline & Pablo O. Rodriguez & $\begin{array}{l}\text { - Pulmonary and Critical Care Medicine } \\
\text { - Centro de Educacion Medica e Investigaciones Clinicas (CEMIC) }\end{array}$ \\
\hline Brazil & $\begin{array}{l}\text { Aldo Agra de Albuquerque } \\
\text { Neto }\end{array}$ & $\begin{array}{l}\text { - Unidade de Reabilitação Pulmonar, Universidade Federal de São } \\
\text { Paulo (Unifesp) }\end{array}$ \\
\hline Colombia & Carlos Torres & $\begin{array}{l}\text { - Director, Research Department, Fundacion Neumologica } \\
\text { Colombiana }\end{array}$ \\
\hline \multirow[t]{2}{*}{ Mexico } & $\begin{array}{l}\text { Rafael J. Hernandez } \\
\text { Zenteno }\end{array}$ & - Head of COPD Clinic, National Institute of Respiratory Diseases \\
\hline & Luis Septien & - Instituto Nacional de Ciencias Medicas y Nutricion Salvador Zubiran \\
\hline Panama & Reynaldo Chandler & $\begin{array}{l}\text { - Professor of Clinical Pneumology } \\
\text { - Pneumologist and Clinical Investigator, Hospital San Miguel Arcangel }\end{array}$ \\
\hline
\end{tabular}

(B) GSK specialists

\begin{tabular}{|c|c|c|}
\hline Department & Name & Role and Specialty in the Meeting \\
\hline $\begin{array}{l}\text { Regional Medical Affairs and R\&D VP } \\
\text { LATAM }\end{array}$ & Eduardo Ortega-Barría & $\begin{array}{l}\text { - Chairman } \\
\text { - Infectious disease specialty }\end{array}$ \\
\hline Medical Director Caricam Pharma & Jose Romero & $\begin{array}{l}\text { - Co-chairman } \\
\text { - Medical doctor }\end{array}$ \\
\hline Vaccines Medical Manager & Laura Naranjo & $\begin{array}{l}\text { - Speaker } \\
\text { - Facilitator } \\
\text { - Infectious disease specialty }\end{array}$ \\
\hline Epidemiology Regional Manager & Patricia Juliao & $\begin{array}{l}\text { - Speaker } \\
\text { - Epidemiologist }\end{array}$ \\
\hline Clinical Operations LATAM Head & Bruno Anspach & $\begin{array}{l}\text { - Observer } \\
\text { - Timekeeper } \\
\text { - Clinical research }\end{array}$ \\
\hline $\begin{array}{l}\text { Clinical and Epidemiology R\&D Project } \\
\text { Lead }\end{array}$ & Ashwani Arora & $\begin{array}{l}\text { - Speaker } \\
\text { - Clinical research }\end{array}$ \\
\hline Epidemiology Regional Manager & Adriana Guzman Holst & $\begin{array}{l}\text { - Scriber } \\
\text { - Epidemiologist }\end{array}$ \\
\hline
\end{tabular}

Abbreviations: CEMIC, Centro de Educacion Medica e Investigaciones Clinicas; COPD, chronic obstructive pulmonary disease; EPOC.AR, Enfermedad Pulmonar Obstructiva Crónica en Argentina; LATAM, Latin America; R\&D, research and development; VP, vice president; Unifesp, Universidade Federal de São Paulo. 


\section{Phase I: Before the AdBoard: Literature} Review

(a) The GSK medical and epidemiology team conducted an integrated literature search on current disease burden evidence, and evidence gaps relevant to AECOPD in LATAM. The PubMed database was searched with a general query search strategy using the following terms (in English, Portuguese, and Spanish): COPD, exacerbations, Acute Exacerbations of Chronic Obstructive Pulmonary Disease, Latin America, epidemiology, prevalence, etiology.

(b) A list of guiding questions was co-developed by the GSK participants and experts for the assessment of each country's AE-COPD data. These questions were approved by the experts before the meeting, in order for them to prepare a summary of the existing local data pertaining to AE-COPD in their respective countries.

Guiding questions:

- What data are available in the country on the epidemiological profile, diagnosis, classification, etiology, and antibiotic resistance of AE-COPD?

- What are the current guidelines to characterize and confirm the etiology of AE-COPD, and who performs the diagnostic procedures?

- In which healthcare setting are AE-COPD patients being treated?

\section{Phase II: During the AdBoard: Expert's Country-Specific Data Review}

(a) The literature review findings were presented by the GSK team to all AdBoard members.

(b) The members of the AdBoard presented their data assessment per country based on the list of guiding questions.

\section{Phase III: During the AdBoard: Panel Discussions and Recommendations}

(a) An open discussion followed the data presentation, where the main findings of the literature review and the expert's data were discussed and summarized.

(b) The experts made recommendations during the meeting.

(c) Extensive meeting minutes were developed to incorporate all parts of the discussion and summarize the main points and recommendations. The final report was structured according to the specific guiding questions and respective outcomes based on the discussions generated by the expert's presentations and review of the published literature.

\section{Results}

\section{AdBoard Panel}

Eight experts participated from five LATAM countries: three from Argentina, one from Brazil, one from Colombia, two from Mexico, and one from Panama (Table 1). The GSK team consisted of seven members (Table 1), who were assigned specific roles during the AdBoard.

\section{Literature Review}

This literature search and review retrieved the epidemiological studies presented in Table 2, based on which the COPD prevalence in the general population varies between $7.8 \%$ in Mexico City and $19.7 \%$ in Montevideo (Projeto Latino-Americano de Investigação em Obstrução Pulmonar (PLATINO) study). ${ }^{22}$ These studies do not generally include AE-COPD within their endpoints, and do not report on the etiology nor the associated healthcare costs of AE-COPD (Table 2). Only one multicenter study (Enfermedad Pulmonar Obstructiva Crónica en Acción (EPOCA) study) reports the number of exacerbations and hospital admissions (Table 2).

A systematic review and meta-analysis by Ciapponi et al reported large variability in COPD prevalence among countries in LATAM, five times higher in patients aged 60 years and over in comparison with those aged between 40 and 49 years (Table 2), and 1.75 times higher in men $(18.2 \%)$ than in women $(10.4 \%) .{ }^{12}$ The authors reported high economic costs due to exacerbations and hospitalizations. ${ }^{12}$ Only one study, a thesis, ${ }^{3}$ conducted in an outpatient clinic in the State of São Paulo, Brazil, included exacerbations as an endpoint. Half (60/120) of the COPD patients experienced exacerbations during the past year and 21\% (25/120) required hospitalization., ${ }^{3,12}$

\section{AdBoard: Country-Specific AE-COPD Data Review Disease Burden}

During the experts' presentations there was a clear gap in the data available to be reported, with some countries presenting more data than others. Nevertheless, we aimed 
Table 2 Literature Review Results

\begin{tabular}{|c|c|c|c|c|c|c|c|c|}
\hline & $\begin{array}{l}\text { LATAM Countries/ } \\
\text { Cities }\end{array}$ & $\begin{array}{l}\text { Study } \\
\text { Population }\end{array}$ & $\begin{array}{l}\text { Study } \\
\text { Period }\end{array}$ & Age & Endpoints & \multicolumn{3}{|l|}{ Results } \\
\hline \multicolumn{9}{|l|}{ Studies } \\
\hline \multirow[t]{2}{*}{$\begin{array}{l}\text { Echazarreta } \\
\text { et al, "EPOC. } \\
A R^{\prime 32}\end{array}$} & \multirow[t]{2}{*}{$\begin{array}{l}6 \text { urban areas in } \\
\text { Argentina }\end{array}$} & \multirow[t]{2}{*}{$\begin{array}{l}\text { Population- } \\
\text { based }\end{array}$} & \multirow[t]{2}{*}{$2014-2016$} & \multirow[t]{2}{*}{$\begin{array}{l}\geq 40 \\
\text { years }\end{array}$} & $\begin{array}{l}\text { - COPD spirometric } \\
\text { fixed-ratio } \\
\text { prevalence }{ }^{\mathrm{a}} \text { and } \\
\text { LLN prevalence } \\
\text { - Risk factors, clinical } \\
\text { and demographic } \\
\text { characteristics of } \\
\text { COPD }\end{array}$ & \multicolumn{3}{|c|}{$\begin{array}{l}\text { - } \text { COPD prevalence: } \\
\circ \text { GOLD: } 14.5 \% \\
\circ \text { LLN: } 9.4 \% \\
\text { - Underdiagnoses rate: } 77.4 \% \\
\text { - Diagnosis error rate/false positive COPD } \\
\text { diagnosis: } 60.7 \%\end{array}$} \\
\hline & & & & & $\begin{array}{l}\text { - No AE-COPD spe- } \\
\text { cific endpoint }\end{array}$ & \multicolumn{3}{|c|}{ - No outcome relevant to AE-COPD } \\
\hline \multirow{8}{*}{$\begin{array}{l}\text { Lopez Varela } \\
\text { et al, "PUMA"33 }\end{array}$} & \multirow{8}{*}{$\begin{array}{l}\text { Argentina } \\
\text { Colombia } \\
\text { Venezuela } \\
\text { Uruguay }\end{array}$} & \multirow{8}{*}{$\begin{array}{l}\text { At-risk }^{c} \\
\text { individuals } \\
\text { attending } \\
\text { primary care } \\
\text { clinics }\end{array}$} & \multirow[t]{8}{*}{2012} & \multirow{8}{*}{$\begin{array}{l}\geq 40 \\
\text { years }\end{array}$} & \multirow{7}{*}{$\begin{array}{l}\text { - COPD spirometric } \\
\text { fixed-ratio } \\
\text { prevalence }{ }^{\mathrm{a}} \text { and } \\
\text { LLN prevalence }^{\mathrm{b}}\end{array}$} & \multicolumn{3}{|l|}{ Prevalence } \\
\hline & & & & & & & $\begin{array}{l}\text { Fixed } \\
\text { ratio }\end{array}$ & LLN \\
\hline & & & & & & Overall & $20.1 \%$ & $14.7 \%$ \\
\hline & & & & & & Argentina & $29.6 \%$ & $19.3 \%$ \\
\hline & & & & & & Colombia & $26.4 \%$ & $21.8 \%$ \\
\hline & & & & & & Venezuela & $11 \%$ & $8.3 \%$ \\
\hline & & & & & & Uruguay & $17.5 \%$ & $13.6 \%$ \\
\hline & & & & & $\begin{array}{l}\text { - No AE-COPD spe- } \\
\text { cific endpoint } \\
\text { - Self-reported } \\
\text { exacerbation his- } \\
\text { tory was recorded }\end{array}$ & \multicolumn{3}{|c|}{ - No outcome relevant to AE-COPD } \\
\hline \multirow{8}{*}{$\begin{array}{l}\text { Miravitlles et al, } \\
\text { "EPOCA"19 }\end{array}$} & \multirow{8}{*}{$\begin{array}{l}\text { Argentina } \\
\text { Ecuador }\end{array}$} & \multirow{8}{*}{$\begin{array}{l}\text { Outpatients } \\
\text { with COPD } \\
\text { diagnosis }^{d}\end{array}$} & \multirow[t]{8}{*}{ 2005-2006 } & \multirow{8}{*}{$\begin{array}{l}>40 \\
\text { years }\end{array}$} & \multirow{8}{*}{$\begin{array}{l}\text { - } \text { COPD }^{d} \text { clinical and } \\
\text { demographic char- } \\
\text { acteristics, including } \\
\text { exacerbations, hos- } \\
\text { pital admission, and } \\
\text { emergency visits }\end{array}$} & \multicolumn{3}{|l|}{ COPD patients } \\
\hline & & & & & & Number of events ${ }^{e}$ & $\begin{array}{l}\text { Argentina } \\
(\mathrm{N}=128)\end{array}$ & $\begin{array}{l}\text { Ecuador } \\
(\mathrm{N}=134)\end{array}$ \\
\hline & & & & & & Exacerbation & 2 & 0.9 \\
\hline & & & & & & Emergency visits & 1.3 & 0.3 \\
\hline & & & & & & Admissions & 0.5 & 0.4 \\
\hline & & & & & & ICU admissions & 0.2 & 0.0 \\
\hline & & & & & & Visits to GPs & 2.6 & 1.6 \\
\hline & & & & & & $\begin{array}{l}\text { Visits to chest } \\
\text { specialists }\end{array}$ & 4.6 & 2.8 \\
\hline \multirow[t]{2}{*}{$\begin{array}{l}\text { Caballero et al, } \\
\text { "PREPOCOL"34 }\end{array}$} & \multirow[t]{2}{*}{ Colombia } & \multirow{2}{*}{$\begin{array}{l}\text { General } \\
\text { population } \\
\text { selected by } \\
\text { probabilistic } \\
\text { method }\end{array}$} & \multirow[t]{2}{*}{ 2003-2004 } & \multirow[t]{2}{*}{$\begin{array}{l}\geq 40 \\
\text { years }\end{array}$} & $\begin{array}{l}\text { COPD fixed-ratio } \\
\text { spirometric, medical, and } \\
\text { clinical prevalence }^{f}\end{array}$ & \multicolumn{3}{|c|}{$\begin{array}{l}\text { Prevalence ( } \mathrm{N}=5539) \text { : } \\
\text { - Spirometric: } 8.9 \% \\
\text { - Medical: } 3.3 \% \\
\text { - Clinical: } 2.7 \%\end{array}$} \\
\hline & & & & & $\begin{array}{l}\text { - No AE-COPD spe- } \\
\text { cific endpoint }\end{array}$ & \multicolumn{3}{|c|}{ - No outcome relevant to AE-COPD } \\
\hline
\end{tabular}

(Continued) 
Table 2 (Continued).

\begin{tabular}{|c|c|c|c|c|c|c|}
\hline & $\begin{array}{l}\text { LATAM Countries/ } \\
\text { Cities }\end{array}$ & $\begin{array}{l}\text { Study } \\
\text { Population }\end{array}$ & $\begin{array}{l}\text { Study } \\
\text { Period }\end{array}$ & Age & Endpoints & Results \\
\hline \multicolumn{7}{|l|}{ Studies } \\
\hline \multirow[t]{2}{*}{$\begin{array}{l}\text { Menezes et al, } \\
\text { "PLATINO"35 }\end{array}$} & \multirow[t]{2}{*}{$\begin{array}{l}\text { São Paulo, Brazil } \\
\text { Santiago, Chile } \\
\text { Mexico City, Mexico } \\
\text { Montevideo, Uruguay } \\
\text { Caracas, Venezuela }\end{array}$} & \multirow[t]{2}{*}{$\begin{array}{l}\text { General } \\
\text { population } \\
\text { selected by } \\
\text { probabilistic } \\
\text { method }\end{array}$} & \multirow[t]{2}{*}{2002} & \multirow[t]{2}{*}{$\begin{array}{l}\geq 40 \\
\text { years }\end{array}$} & $\begin{array}{l}\text { COPD fixed-ratio } \\
\text { spirometric prevalence }\end{array}$ & $\begin{array}{l}\text { - São Paulo: } 15.8 \% \\
\text { - Santiago: } 16.9 \% \\
\text { - Mexico City: } 7.8 \% \\
\text { - Montevideo: } 19.7 \% \\
\text { - Caracas: } 12.1 \%\end{array}$ \\
\hline & & & & & $\begin{array}{l}\text { - No AE-COPD spe- } \\
\text { cific endpoint }\end{array}$ & - No outcome relevant to AE-COPD \\
\hline \multicolumn{7}{|c|}{ Systematic Reviews } \\
\hline Ciapponi et al ${ }^{12}$ & $\begin{array}{l}\text { LATAM: Argentina, } \\
\text { Brazil, Chile, Colombia, } \\
\text { Ecuador, Mexico, Peru, } \\
\text { Uruguay, Trinidad and } \\
\text { Tobago, and Venezuela }\end{array}$ & $\begin{array}{l}\text { Systematic } \\
\text { review and } \\
\text { meta-analysis } \\
\text { on population- } \\
\text { based } \\
\text { prevalence } \\
\text { studies }\end{array}$ & 2012 & $\begin{array}{l}\geq 40 \\
\text { years }\end{array}$ & $\begin{array}{l}\text { - COPD fixed-ratio } \\
\text { prevalence, risk fac- } \\
\text { tors, and disease } \\
\text { burdeng } \\
\text { - COPD } \\
\text { exacerbations }\end{array}$ & $\begin{array}{l}\text { - } \text { Pooled prevalence: } 13.4 \% \\
\circ \quad 40-49 \text { years: } 5.2 \% \\
\circ 50-59 \text { years: } 11.0 \% \\
\circ \geq 60 \text { years: } 24.3 \% \\
\text { - } \text { Exacerbations: } \\
\circ 50 \% \text { of the patients } \\
\circ 9.5 \text { days median length of hospitalizations }\end{array}$ \\
\hline
\end{tabular}

Notes: ${ }^{a}$ Post-bronchodilator FEVI/FVC $<70 \%$. ${ }^{b}$ Post-bronchodilator FEVI/FVC <lower limit of normal. ${ }^{\mathrm{C} A g e} \geq 40$ years, smoker or former smoker of at least 10 packs per year, and/or exposure to biomass smoke. ${ }^{\mathrm{d}}$ Age $>40$ years, smoker or former smoker of at least 10 pack years, FEVI/FVC < $70 \%$. ${ }^{\mathrm{e}}$ Mean number. $\mathrm{f}^{\mathrm{F}} \mathrm{Fixed-ratio}$ spirometric if $\mathrm{FEVI} / \mathrm{FVC}<70 \%$, medical if there was a history of diagnosis for bronchitis, emphysema, or COPD, and clinical if chronic bronchitis criteria were fulfilled. Involves disease severity, comorbidities, mortality, cost, and resource utilization.

Abbreviations: AE-COPD, acute exacerbations of chronic obstructive pulmonary disease; COPD, chronic obstructive pulmonary disease; EPOCA, Enfermedad Pulmonar Obstructiva Crónica en Acción; EPOC.AR, Enfermedad Pulmonar Obstructiva Crónica en Argentina; FEV , forced expiratory volume in one second; FVC, forced vital capacity; GOLD, Global Initiative for Chronic Obstructive Lung Disease; GP, general practitioner; ICU, intensive care unit; LATAM, Latin America; LLN, lower limit of normal; PLATINO, Projeto Latino-Americano de Investigação em Obstrução Pulmonar; PREPOCOL, Prevalencia de EPOC [COPD] en Colombia; PUMA, Prevalence Study and Regular Practice, Diagnosis and Treatment, Among General Practitioners in Populations at Risk of COPD in Latin America.

to summarize and describe each country's main findings. In Argentina, the available COPD prevalence data were those reported by the Enfermedad Pulmonar Obstructiva Crónica en Argentina (EPOC.AR) study, conducted in the six main urban conglomerates of the country (Table 2). The associated mortality increases with age, especially in men. The experts noted that approximately $77 \%$ of COPD cases are underreported, mainly in patients with mild disease or no reported symptoms. The observed incidence of AE-COPD cases increases during winter in parallel to the increase of other respiratory viruses. However, epidemiological data on this were not available. The AE-COPD cases are treated in the following healthcare settings: social security $(50 \%)$, public insurance $(37 \%)$, and private insurance (14\%).

For Brazil, the only available epidemiological data are those reported for COPD in São Paulo by the PLATINO study (Table 2). No epidemiological data specific to exacerbations are available, but at the expert's institution (Universidade Federal de Sao Paulo), in the year 2017, the prevalence of one exacerbation was $25 \%$ and was $33 \%$ for two or more exacerbations. Although the incidence of
COPD hospitalizations has decreased, COPD-related mortality has increased. At the expert's institution, $42 \%$ of COPD diagnoses are made when the disease is mild, $24 \%$ with moderate symptoms, and $33 \%$ when the disease is severe.

Colombia reported the lowest COPD prevalence, as shown by the Estudio de Prevalencia de EPOC [COPD] en Colombia (PREPOCOL) data (Table 2). The expert reported an $87 \%$ underdiagnosis level. However, in Colombia, COPD is the third most common cause of death above 65 years of age and is the second most common reason for disabilityadjusted life years (DALYs) lost in this group of age. No specific data about exacerbations were available. Most of the population has coverage by the public Health System. In an institution specialized in respiratory health in Bogota (Fundación Neumológica Colombiana), the COPD patients are treated within a specific integrated program for COPD named AIREPOC (Programa de Atención Integral, Rehabilitación y Educación de Pacientes con EPOC). Most of the patients in this program are moderate or severe cases, and less than $15 \%$ are mild. The classification of AE-COPD severity may depend on multiple factors such as treatment 
regimen, symptom severity (ambulatory versus hospitalization), physical examination, history of comorbidities, and results of paraclinical tests (ie, spirometry, X-rays, etc.). A mild AE-COPD case would be ambulatory and receive increasing doses of bronchodilators; a moderate case would also be ambulatory but would require antibiotics and corticosteroids. A severe case would be hospitalized and receive antibiotics and corticosteroids. Antibiotics are also administered to all ambulatory cases with sputum. Finally, the expert remarked that although the assignment of AE-COPD to a severity stage is difficult, this should always be based on actual clinical endpoints/diagnosis and not on resources used, such as antibiotics or hospitalization.

For Mexico, the only available epidemiological information is the relatively low COPD prevalence reported for Mexico City in the multicenter PLATINO study (Table 2). The experts reported that seven out of ten hospital admissions due to COPD are associated with exacerbations. Experts estimate that $35-50 \%$ are moderate COPD cases, and less than $35 \%$ are severe. AE-COPD is managed differently in inpatients and outpatients depending on the patient's comorbidities and associated cost.

For Panama, there is a lack of any data on COPD, exacerbations, and other non-transmissible chronic diseases. COPD-associated mortality cannot be estimated as it is categorized within the overall group of respiratory diseases.

\section{Diagnostic and Treatment Guidelines}

The experts from all five countries follow the international GOLD guidelines in a standardized manner and reported limited local guidelines for AE-COPD diagnosis and treatment. In Argentina, ${ }^{23,24}$ AE-COPD severity classification is based on clinical signs and symptoms; however, this definition is problematic due to the subjective nature of these clinical criteria as well as exclusion of other differential diagnoses such as pneumonia. Etiology exploration can be heterogeneous, as there is no widely accepted guideline for this. In Argentina, the influenza vaccine forms part of the National Immunization Program, and since 2017 pneumococcal conjugated vaccine and polysaccharide vaccine are recommended and free of charge for COPD patients. Colombia has Clinical Practice Guidelines for COPD-patient management, ${ }^{25,26}$ which include recommendations for prevention, diagnosis (including evaluation of the etiology), and treatment of AE-COPD. In particular, the Colombian guidelines recommend specific antibiotics and proposed corticosteroid bursts and also recommend influenza and pneumococcal vaccines for COPD patients. In Brazil, the local guideline shows how to identify an exacerbation, the recommended treatment, and the criteria to consider hospitalization. ${ }^{27}$ Mexico has one national guideline for COPD and for vaccines administered in COPD patients. ${ }^{28}$ Panama does not have national guidelines for COPD and exacerbations, and sample cultures are done only upon failure of empirical antibacterial treatment.

\section{Etiology Data}

The etiology data presented at the country level cannot be compared due to key differences in the sample and data collection, sample size, institution type (ie, clinic vs hospital), and methods (ie, assays) used to analyze the data. Most data are collected from the expert's routine clinical practice, including laboratory testing, and not formalized studies. Therefore, the data are summarized individually by country.

Official information on viral or bacterial etiology is not available in Argentina, because the clinical specimens required for analysis are not regularly collected before diagnosis or, when collected, the patient might already have received antibiotic treatment. Collection of clinical specimens is also not routinely recommended for AECOPD, particularly for ambulatory care patients. Furthermore, the official country surveillance data cover all respiratory viral and bacterial pathogen isolates with no specific mention of the diagnosis of the patients.

The Brazilian expert reported that M. catarrhalis and Streptococcus pneumoniae have been observed to circulate in the country's general population, but quantitative data are not available. Sample collection is not routinely recommended in the outpatient setting and sputum cultures are feasible but not recommended in outpatients. In severe cases with treatment failure, a sample is collected to identify the etiology by culture and molecular techniques.

In Colombia, the expert presented that M. catarrhalis and H. influenzae are the main bacterial isolates from patients with severe COPD exacerbations. ${ }^{29}$ Although these data cannot be extrapolated for non-intensive care unit (ICU) patients, they are an indication of the distribution of the bacterial etiology of AE-COPD for hospitalized patients: H. influenzae 25\%, M. catarrhalis $25 \%$, H. parainfluenzae: $15 \%$, Pseudomonas spp. $6 \%$, and $S$. pneumoniae $7 \%$. In general, no etiology evaluation test is performed for ambulatory patients or in nonsevere patients without risk factors. In the presence of purulence and risk factors, culture of sputum and Gram staining with sensitivity testing are performed. Hospitalized patients 
also undergo several tests including hemogram, C-reactive protein, blood culture and Gram staining, and a film array panel for intensive care patients to determine the etiology.

There is scarce information about AE-COPD from Mexico. In one study in 2008, a high prevalence of unexpected Gram-negative enteric bacilli (30\%) and Pseudomonas (16\%) in a mild exacerbation of the early stages of COPD (from 53\% positive cultures, pathogen prevalences were $H$. influenzae $20 \%$, M. catarrhalis $16 \%$ S. pneumoniae 14\%). This information may be relevant for prescribing antibiotics in a local setting. ${ }^{30}$ In severe AECOPD (including biomass COPD), the prevalence of isolated virus was $37 \%$ and for bacterial was $19 \%$, whereas for stable COPD this was $12 \%$ and $27 \%$ respectively, and $7 \%$ had M. catarrhalis (both studies were carried out at the COPD Clinic at INER [Instituto Nacional de Enfermedades Respiratorias]). ${ }^{31}$

No etiology data were available for Panama.

\section{AdBoard: Panel Discussion and Recommendations \\ Disease Burden and Diagnostic Procedures}

Several recommendations came out to the panel discussion. First, AE-COPD epidemiological data in LATAM must be generated, as they are currently very limited. Second, the problem of underdiagnosis must be tackled. Eighty percent of COPD patients are not hospitalized, and when they are admitted to emergency units, sometimes their disease is not accurately coded and there is no proper differential diagnosis which leads to disease misclassification. Due to this misclassification, these patients are not referred to a pulmonologist. Third, hospital data are biased toward severe cases of all types of respiratory disease and there is no clear strategy to assess severity. Severity is assessed based on resource utilization, thus an ambulatory case requiring antibiotic treatment is considered moderate and is treated in the outpatient setting, whilst a case requiring hospitalization is considered severe. Two main recommendations were proposed to address the three points above.

Recommendation 1: prospective cohort epidemiological studies for evaluating the disease burden and clinical characteristics of COPD should be conducted in LATAM countries, with a suggested follow-up period of more than 1 year to better assess the disease severity and etiology. In these studies, the AE-COPD must be classified as mild, moderate, or severe based on clinical and non-clinical parameters. An appropriate differential diagnosis, especially with asthma, and etiology testing, including viral infections, should be strongly recommended.

Data should not be generalized within or between different countries because different environments and conditions, risk factors, sociodemographic factors, and genetics could differentially affect epidemiological data.

Recommendation 2: respiratory samples from COPD patients should be routinely collected (at diagnosis or during exacerbations or both) and analyzed for identification of etiology (ie, bacterial pathogens and viruses). Clinicians should inform the laboratory staff about the clinical history and diagnosis of the COPD patient, so that they can more precisely assess the presence of pathogens. The appropriate indications, conditions, and standards for taking, processing, and interpreting these samples should be defined at each country level. It is strongly recommended that epidemiological profiles of the infectious etiology of AE-COPD should be locally defined.

\section{Etiology Evaluation}

The country-specific presentations by the experts made clear that in the LATAM countries, the most frequent situation in the clinical practice of AE-COPD is the ambulatory care and treatment of AE-COPD, without routine etiology evaluation. When an etiology examination is considered, the performance and interpretation of the results are limited by: 1) previous antibiotic use for treatment that inhibits culture and isolation of pathogens (considering that in some countries the antibiotics are given without prescription); and 2) samples contaminated with a high concentration of oropharyngeal floral bacteria. Two recommendations were made by the AdBoard regarding etiology evaluation.

Recommendation 1: etiologic studies (and characterization of AE-COPD phenotypes) should be conducted prospectively combining patients' clinical and laboratory findings with routine respiratory pathogen surveillance and resistance profiles within the country. The results of such a study should be used to assess each country's existing guidelines and develop recommendations on diagnostic procedures.

Recommendation 2: a prospective bacteriological study with at least 1 year of follow-up and monthly collection of samples for bacterial evaluation. Patients with mild, moderate, and severe disease should be enrolled, with and without exacerbations to allow comparison between stable disease and rates of exacerbations. 


\section{Plain Language Summary}

\section{What is the context?}

- High prevalence of Chronic Obstructive Pulmonary Disease (COPD) and acute exacerbations in Latin American countries

\section{What is new?}

- Limited standardized definition of the diseases

- Limited clear distinction between the disease and its exacerbations

- Limited data on disease management

- Limited country-level on burden and epidemiology

- Limited data on etiology

Figure I Relevance, aims, and main findings of the study.

\section{Conclusions}

The AE-COPD LATAM AdBoard meeting identified significant evidence gaps with respect to disease etiology and disease diagnosis (Figure 1). There is an unclear distinction between AE-COPD disease diagnosis and exacerbations. There are very limited data on the AE-COPD burden and epidemiology, and even less on etiology. Lastly, limited data are available on management of disease, either in the outpatient or inpatient setting.

The AdBoard discussions resulted in recommendations for future research. Studies should be designed based on the local epidemiological data and clinical infrastructure. The experts recommended that these studies should be conducted for a follow-up period of more than 1 year, use clear case definitions and severity diagnosis as the main criteria for the categorization of AE-COPD, and evaluate etiology.

\section{Abbreviations}

AE-COPD, acute exacerbation of chronic obstructive pulmonary disease; AIREPOC, Programa de Atención Integral, Rehabilitación y Educación de pacientes con EPOC de la Fundación Neumológica Colombiana; COPD, chronic obstructive pulmonary disease; CRP,
C-reactive protein; DALYs, disability-adjusted life years; EPOCA, Enfermedad Pulmonar Obstructiva Crónica en Acción; EPOC.AR, Enfermedad Pulmonar Obstructiva Crónica en Argentina; $\mathrm{FEV}_{1}$, forced expiratory volume in one second; FVC, forced vital capacity; GOLD, Global Initiative for Chronic Obstructive Lung Disease; GP, general practitioner; ICU, intensive care unit; INER, Instituto Nacional de Enfermedades Respiratorias; LATAM, Latin America; NTHi, nontypeable Haemophilus influenzae; PLATINO, Projeto Latino-Americano de Investigação em Obstrução Pulmonar; PREPOCOL, Estudio de Prevalencia de EPOC [COPD] en Colombia; SABs, short acting bronchodilators.

\section{Acknowledgments}

The authors thank Ashwani Arora for the support in planning and presenting during the AdBoard meeting. The authors would like to thank Business \& Decision Life Sciences platform for editorial assistance and manuscript coordination, on behalf of GSK. Pierre-Paul Prévot coordinated manuscript development and editorial support. The authors also thank Athanasia Benekou (Business \& Decision Life Sciences, on behalf of GSK) for providing medical writing support. 


\section{Author Contributions}

All authors made substantial contributions to conception and design, acquisition of data, or analysis and interpretation of data; took part in drafting the article or revising it critically for important intellectual content; agreed to submit to the current journal; gave final approval of the version to be published; and agree to be accountable for all aspects of the work.

\section{Funding}

GlaxoSmithKline Biologicals S.A. funded this study and all costs related to the development of related publications.

\section{Disclosure}

Laura Naranjo, Eduardo Ortega-Barria, and Patricia Juliao are employees of the GSK group of companies hold shares in it. Adriana Guzman-Holst is an employee of the GSK group of companies. All non-GSK affiliated authors received a standard honorarium fee, based on established policies, for their consultancy agreement during the development and participation of the Advisory Board. The authors report no other conflicts of interest in this work.

\section{References}

1. Chronic Obstructive Pulmonary Disease (COPD) in the Americas. 2014.

2. Global Intitiative for Chronic Obstructive Lung Disease. Global Strategy for the Diagnosis, Management, and Prevention of Chronic Obstructive Lung Disease. 2019 Report. Accessed 13 June 2019.

3. Faganello MM Factors associated with occurrence of exacerbations in patients with COPD. Available from: https://repositorio.unesp.br/han dle/11449/102611: Universidade Estadual Paulista, Faculdade de Medicina de Botucatu 2007.

4. Montes de Ocaa M, López Varelab MV, Acuñac A, et al. Guía de práctica clínica de la enfermedad pulmonar obstructiva crónica (EPOC) ALAT-2014: preguntas y respuestas. Arch Bronconeumol. 2015;51(8):14. doi:10.1016/j.arbres.2014.11.017

5. WHO. Global surveillance, prevention and control of chronic respiratory diseases. A comprehensive approach. 2007; 18 June. 2019. Accessed 18 June 2019.

6. Anthonisen NR, Manfreda J, Warren CP, Hershfield ES, Harding GK, Nelson NA. Antibiotic therapy in exacerbations of chronic obstructive pulmonary disease. Ann Intern Med. 1987;106(2):196-204. doi:10.7326/0003-4819-106-2-196

7. Wedzicha JA, Donaldson GC. Exacerbations of chronic obstructive pulmonary disease. Respir Care. 2003;48(12):1204-1205.

8. Soler-Cataluna JJ, Martinez-Garcia MA, Roman Sanchez P, Salcedo E, Navarro M, Ochando R. Severe acute exacerbations and mortality in patients with chronic obstructive pulmonary disease. Thorax. 2005;60 (11):925-931. doi:10.1136/thx.2005.040527

9. Miravitlles M, Ferrer M, Pont A, et al. Effect of exacerbations on quality of life in patients with chronic obstructive pulmonary disease: a 2 year follow up study. Thorax. 2004;59(5):387-395. doi:10.1136/ thx.2003.008730

10. Viniol C, Vogelmeier CF. Exacerbations of COPD. Eur Respir Rev. 2018;27:147. doi:10.1183/16000617.0103-2017
11. Montes de Oca M, Talamo C, Halbert RJ, et al. Frequency of self-reported COPD exacerbation and airflow obstruction in five Latin American cities: the proyecto latinoamericano de investigacion en obstruccion pulmonar (PLATINO) study. Chest. 2009;136 (1):71-78. doi:10.1378/chest.08-2081

12. Ciapponi A, Alison L, Agustina M, Demian G, Silvana C, Edgardo S. The epidemiology and burden of COPD in Latin America and the Caribbean: systematic review and meta-analysis. COPD. 2014;11 (3):339-350. doi:10.3109/15412555.2013.836479

13. Miravitlles M, Jardim JR, Zitto T, Rodrigues JE, Lopez H. Estudio farmacoeconómico del tratamiento antibiótico de las agudizaciones de la bronquitis crónica y la EPOC en Latinoamérica. [Pharmacoeconomic study of antibiotic therapy for exacerbations of chronic bronchitis and chronic obstructive pulmonary disease in Latin America]. Arch Bronconeumol. 2003;39(12):549-553. Spanish. doi:10.1016/S0300-2896(03)75453-2

14. Koblizek V, Novotna B, Zbozinkova Z, Hejduk K. Diagnosing COPD: advances in training and practice - a systematic review. $A d v$ Med Educ Pract. 2016;7:219-231. doi:10.2147/AMEP.S76976

15. Lamprecht B, Soriano JB, Studnicka M, et al. Determinants of underdiagnosis of COPD in national and international surveys. Chest. 2015;148(4):15. doi:10.1378/chest.14-2535

16. Almagro P, Soriano JB. J.B. S. Underdiagnosis in COPD: a battle worth fighting. Lancet Respir Med. 2017;5(5):2. doi:10.1016/S22132600(17)30133-9

17. Miravitlles M, Mayordomo C, Artes M, Sanchez-Agudo L, Nicolau F, Segu JL. Treatment of chronic obstructive pulmonary disease and its exacerbations in general practice. EOLO group. Estudio observacional de la limitacion obstructiva al flujo aEreo. Respir Med. 1999;93 (3):173-179. doi:10.1016/S0954-6111(99)90004-5

18. Aisanov Z, Bai C, Bauerle O, et al. Primary care physician perceptions on the diagnosis and management of chronic obstructive pulmonary disease in diverse regions of the world. Int J Chron Obstruct Pulmon Dis. 2012;7:271-282. doi:10.2147/COPD.S28059

19. Miravitlles M, Murio C, Tirado-Conde G, et al. Geographic differences in clinical characteristics and management of COPD: the EPOCA study. Int $J$ Chron Obstruct Pulmon Dis. 2008;3 (4):803-814. doi:10.2147/COPD.S4257

20. Calle Rubio M, Lopez-Campos JL, Soler-Cataluna JJ, et al. Variability in adherence to clinical practice guidelines and recommendations in COPD outpatients: a multi-level, cross-sectional analysis of the EPOCONSUL study. Respir Res. 2017;18(1):200. doi:10.1186/s12931-017-0685-8

21. Roberts CM, Lopez-Campos JL, Pozo-Rodriguez F, Hartl S; European CAt. European hospital adherence to GOLD recommendations for chronic obstructive pulmonary disease (COPD) exacerbation admissions. Thorax. 2013;68(12):1169-1171. doi:10.1136/thoraxjnl2013-203465

22. Menezes AM, Perez-Padilla R, Jardim JR, et al. Chronic obstructive pulmonary disease in five Latin American cities (the PLATINO study): a prevalence study. Lancet. 2005;366(9500):1875-1881. doi:10.1016/S0140-6736(05)67632-5

23. Lopardo G, Pensotti C, Scapellato P, et al. Consenso intersociedades para el manejo de infecciones respiratorias: bronquitis aguda Y enfermedad pulmonar obstructiva crónica. Medicina. 2013;73:11.

24. Campbell S, Forbes BA. The clinical microbiology laboratory in the diagnosis of lower respiratory tract infections. J Clin Microbiol. 2011;49(9):1. doi:10.1128/JCM.00789-11

25. Londoño D, García OM, Celis C, et al. Guía de práctica clínica basada en la evidencia para la prevención, diagnóstico, tratamiento y seguimiento de la enfermedad pulmonar obstructiva crónica (EPOC) en población adulta. Acta Med Colomb. 2014;39(2):48.

26. Gómez Muñoza JM, Gómez Rincón JC, Munive AA, et al. Guías para la inmunización del adolescente y adulto en Colombia. Documento de actualización, 2016. Infectio. 2016;20(4):19. 
27. Lundgren F, Maranhão B, Jardim JR, et al. Doença Pulmonar Obstrutiva Crônica: exacerbação. 2012.

28. Salud S Diagnostico y tratamiento de la enfermedad pulmonar obstructiva, Mexico. 2009.

29. Varon F, Torres-Caro C, Herrera-Diaz C, et al. Microbiological characterization of severe exacerbations in Chronic Obstructive Pulmonary Disease (COPD) in patients admitted to the ICU with or without associated pneumonia: a retrospective cross-sectional study. Infectio. 2019;23(4):6. doi:10.22354/in.v23i4.803

30. Padua J, Ramirez-Venegas A, Hernandez-Zenteno RJ, SanchezRomero C, Quiñones-Falconi F, Sansores-Martinez RH. P2300 high prevalence of gramnegative enteric bacilli and pseudomonas in mild exacerbation of early stages COPD (GoldI-II). Eur Respir J. 2008;32.

31. Paulin-Prado P, Bautista-Félix N, Velazquez-Uncal M, et al. Are viral infections associated to severe exacerbation in Chronic Obstructive Pulmonary Disease (COPD) due to biomass exposure? Am J Respir Crit Care Med. 2016;193:A5187.

32. Echazarreta AL, Arias SJ, Del Olmo R, et al. Prevalence of COPD in 6 urban clusters in Argentina: the EPOC.AR study. Arch Bronconeumol. 2018;54(5):260-269. doi:10.1016/j.arbres.2017.09.018
33. Lopez Varela MV, Montes de Oca M, Rey A, et al. Development of a simple screening tool for opportunistic COPD case finding in primary care in Latin America: the PUMA study. Respirology. 2016;21(7):1227-1234. doi:10.1111/resp.12834

34. Caballero A, Torres-Duque CA, Jaramillo C, et al. Prevalence of COPD in five Colombian cities situated at low, medium, and high altitude (PREPOCOL study). Chest. 2008;133(2):343-349. doi:10.1378/chest.07-1361

35. Menezes AM, Jardim JR, Perez-Padilla R, et al. Prevalence of chronic obstructive pulmonary disease and associated factors: the PLATINO study in Sao Paulo, Brazil. Cad Saude Publica. 2005;21 (5):1565-1573. doi:10.1590/S0102-311X2005000500030

\section{Publish your work in this journal}

The International Journal of COPD is an international, peer-reviewed journal of therapeutics and pharmacology focusing on concise rapid reporting of clinical studies and reviews in COPD. Special focus is given to the pathophysiological processes underlying the disease, intervention programs, patient focused education, and self management protocols. This journal is indexed on PubMed Central, MedLine and CAS. The manuscript management system is completely online and includes a very quick and fair peer-review system, which is all easy to use. Visit http://www.dovepress.com/testimonials.php to read real quotes from published authors. 